\title{
Memórias dum Átomo
}

\author{
EÇA DE Q UEIROZ
}

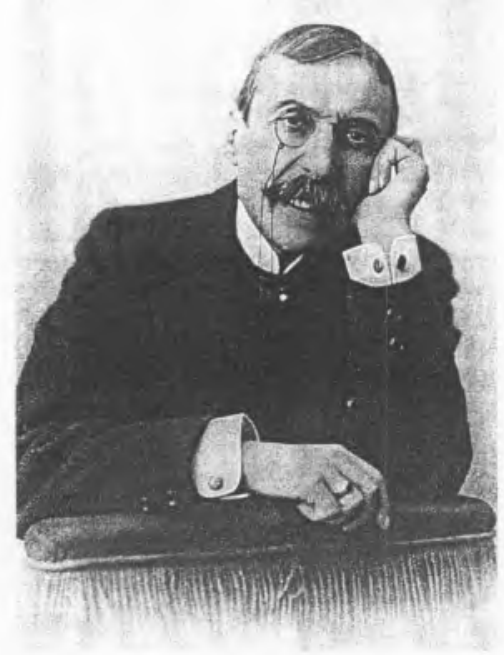

Eça de Queiroz (1845-1900) João da Ega, (...) com a sua figura esgrouviada e seca, os pêlos do bigode arrebitados sob o nariz adunco, um quadrado de vidro entalado no olho direito - tinha realmente alguma coisa de rebelde e de satânico.

(...) Ao outro dia, com efeito, Afonso veio encontrá-lo na sala de bilhar - onde tinham sido colocados os caixotes - a despregar, a desempacotar, em mangas de camisa e assobiando com entusiasmo. Pelo chão, pelos sofás, alastrava-se toda uma literatura em rumas de volumes graves; aqui e além, por entre a palha, através das lonas descosidas, a luz faiscava num cristal, ou reluziam os vernizes, os metais polidos de aparelhos. Afonso pasmava em silêncio para aquele pomposo aparato do saber.

- E onde vais tu acomodar este museu?

Carlos pensara em arranjar um vasto laboratório ali perto do bairro, com fornos para trabalhos químicos, uma sala disposta para estudos anatómicos e fisiológicos, a sua biblioteca, os seus aparelhos, uma concentração metódica de todos os instrumentos de estudo...

Os olhos do avô iluminavamse ouvindo este plano grandioso.

- E que não te prendam questões de dinheiro, Carlos! Nós fizemos nestes últimos anos de Santa Olávia algumas economias...

- Boas e grandes palavras. avô! Repita-as ao Vilaça.

As semanas foram passando nestes planos de instalação. Carlos trazia realmente resoluções sinceras de trabalho: a ciência como mera ornamentação interior do espírito, mais inútil para os outros que as próprias tapeçarias do seu quarto, parecia-lhe apenas um luxo de solitário: desejava ser útil. Mas as suas ambições flutuavam, intensas e vagas; ora pensava numa larga clínica; ora na composição maciça de um livro iniciador; algumas vezes em experiências fisiológicas, pacientes e reveladoras... Sentia em si, ou supunha sentir, o tumulto de uma força, sem lhe discernir a linha de aplicação. "Alguma coisa de brilhante", como ele dizia: e isto para ele, homem de luxo e homem de estudo, significava um conjunto de representação social e de actividade científica; o remexer profundo de ideias entre as influências delicadas da riqueza; os elevados vagares da filosofia entremeados com requintes de sport e de gosto; um Claude Bernard que fosse também um Morny...

No fundo era um dilettante.

Vilaça fora consultado sobre a localidade própria para o laboratório; e o procurador, muito lisonjeado, jurou uma diligência incansável. Primeira coisa a saber, o nosso doutor tencionava fazer clínica?...

Carlos não dicidira fazer exclusivamente clínica: mas desejava decerto dar consultas, mesmo gratuitas como caridade e como prática. Então Vilaça sugeriu que o consultório estivesse separado do laboratório.

- E a minha razão é esta: a vista de aparelhos, máquinas, coisas, faz esmorecer os doentes...

Tem você razão, Vilaça! exclamou Afonso. - Já meu pai dizia: poupe-se ao boi a vista do malho.
- Separados, separados, meu senhor - afirmou o procurador num tom profundo.

Carlos concordou. E Vilaça bem depressa descobriu, para o laboratório, um antigo armazém, vasto e retirado, ao fundo de um pátio, junto ao Largo das Necessidades.

(...) Ocupava-se então mais do laboratório, que decidira instalar no armazém, às Necessidades. Todas as manhãs, antes de almoço, ia visitar as obras. Entrava-se por um grande pátio, onde uma bela sombra cobria um poço, e uma trepadeira se mirrava nos ganchos de ferro que a prendiam ao muro. Carlos já dicidira transformar aquele em fresco jardinete inglês; e a porta do casarão encantava-o, ogival e nobre, resto de fachada de ermida, fazendo um acesso venerável para o seu santuário de ciência. Mas dentro os trabalhos arrastavam-se sem-fim; sempre um vago martelar preguiçoso numa poeira alvadia, sempre as mesmas coisas de ferramentas jazendo nas mesmas camadas de aparas! Um carpinteiro esgrouviado e triste parecia estar ali, desde séculos, aplainando uma tábua eterna com uma fadiga langorosa; e no telhado os trabalhadores, que andavam alargando a clarabóia, não cessavam de assobiar, no sol de Inverno, alguma lamúria de fado.

Carlos queixava-se ao $\mathrm{Sr}$. Vicente, o mestre de obras, que lhe asseverava invariavelmente "como daí a dois dias havia de S. Exa. ver a diferença".

$$
\text { (...) }
$$

Os almoços no Ramalhete eram sempre delicados e longos; depois, ao café, ficavam ainda conversando; e passava da uma hora, da hora e meia, quando Carlos, com uma exclamação, precipitando-se sobre o relógio se lembrava do seu consultório. Bebia um cálix de Chartreuse, acendia à pressa um 
charuto:

- Ao trabalho, ao trabalho! exclamava.

E o avô, enchendo devagar o seu cachimbo, invejava-lhe aquela ocupação, enquanto ele ficava ali a vadiar toda a manhã..

- Quando esse eterno laboratório estiver acabado, talvez vá para lá passar um bocado, ocuparme de química.

- E ser talvez um grande químico. $\mathrm{O}$ avô tem já o feitio.

$\mathrm{O}$ velho sorria.

- Esta carcassa já não dá nada, filho. Está pedindo eternidade!

(...)

Já nos degraus da escada, voltou-se, entalou o monóculo, gritou para cima:

- Tinha-me esquecido dizer-te, vou publicar o meu livro!

- O quê! está pronto? - exclamou Carlos, espantado.

- Está esboçado, à broxa larga...

O Livro do Ega! Fora em Coimbra, nos dois últimos anos, que ele começara a falar do seu livro, contando o plano, soltando títulos de capítulos, citando pelos cafés frases de grande sonoridade. E entre os amigos do Ega discutia-se já o livro do Ega como devendo iniciar, pela forma e pela ideia, uma evolução literária. Em Lisboa (onde ele vinha passar as férias $\mathrm{e}$ dava ceias no Silva) o livro fora anunciado como um acontecimento. Bacharéis, contemporâneos ou seus condiscípulos, tinham levado de Coimbra, espalhado pelas províncias e pelas ilhas, a fama do livro do Ega. Já de qualquer modo essa notícia chegara ao Brasil. E sentindo esta ansiosa espectativa em torno do seu livro - o Ega decidira-se enfim a escrevê-lo.

Devia ser uma epopeia em prosa, como ele dizia, dando, sob episódios simbólicos, a história das grandes fases do Universo e da Humanidade. Intitulava-se Memórias dum Átomo, e tinha a forma duma autobiografia. Este átomo (o átomo do Ega, como se lhe chamava a sério em Coimbra), aparecia no primeiro capítulo, rolando ainda no vago das Nebuloses pri- mitivas: depois vinha embrulhado, faísca candente, na massa de fogo que devia ser mais tarde a Terra: enfim, fazia parte da primeira folha de planta que surgiu da crosta ainda mole do globo. Desde então, viajando nas incessante transformações da substância, o átomo do Ega entrava na rude estrutura do Orango, pai da humanidade - e mais tarde vivia nos lábios de Platão. Negrejava no burel dos santos, refulgia na espada dos heróis, palpitava no coração dos poetas. Gota de água nos lagos de Galileia, ouvira o falar de Jesus, aos fins da tarde, quando os apóstolos recolhiam as redes; nó de madeira na tribuna da Convenção, sentira o frio da mão de Robespierre. Errara nos vastos anéis de Saturno; e as madrugadas da terra tinham-no orvalhado, pétala resplandecente de um dormente e lânguido lírio. Fora omnipresente, era omnisciente. Achando-se finalmente no bico da pena do Ega, e cansado desta jornada através do Ser, repousava - escrevendo as suas Memórias... Tal era este formidável trabalho de que os admiradores do Ega, em Coimbra, diziam, pensativos e como esmagados de respeito:

\section{- É uma Bíblia!}

(...)

Dias depois Carlos, no consultório, acabava de despedir um doente, um Viegas, que todas as semanas vinha ali fazer a fastidiosa crónica da sua dispepsia - quando do reposteiro da sala de espera the surgiu o Ega, de sobrecasaca azul, luva gris-perle e um rolo de papel na mão.

- Tens que fazer, doutor?

- Não, ia a sair, janota!

- Bem. Venho-te impingir prosa... Um bocado do Atomo... Senta-te aí. Ouve lá.

Imediatamente abancou, afastou papéis e livros, desenrolou o manuscrito, espalmou-o, deu um puxão ao colarinho - e Carlos, que se pousara à borda do divã, com a face espantada e as mãos nos joelhos, achou-se quase sem transição transportado dos rugidos do ventre do Viegas para um rumor de populaça, num bairro de judeus, na velha cidade de Heidelberga.

- Mas espera lá! - esclamou ele. - Deixa-me respirar. Isso não é o começo do livro! Isso não é o caos...

Ega então recostou-se, desabotoou a sobrecasaca, respirou também.

- Não, não é o primeiro episódio... Não é o caos. É já no século XV... Mas num livro destes pode-se começar pelo fim... Conveio-me fazer este episódio: chama-se a Hebreia.

- A Cohen! - pensou Carlos.

Ega tornou a alargar o colarinho - e foi lendo, animando-se, ferindo as palavras para as fazer viver, soltando grandes cheios de voz nas sonoridades finais dos períodos. Depois da sombria pintura dum bairro medieval de Heidelberga, o famoso Átomo, o Átomo do Ega, aparecia alojado no coração do esplêndido príncipe Franck, poeta, cavaleiro e bastardo do imperador Maximiliano. E todo esse coração de herói palpitava pela judia Ester, pérola maravilhosa do Oriente, filha do velho rabino Salomão, um grande doutor da Lei, perseguido pelo ódio teológico do Geral dos Dominicanos.

Isto contava-o o Átomo num monólogo, tão recamado de imagens como um manto da-Virgem está recamado de estrelas - e que era uma declaração dele, Ega, à mulher do Cohen. Depois abria-se um intermédio panteísta: rompiam coros de flores, coros de astros, cantando na linguagem da luz, ou na eloquência dos perfumes, a beleza, a graça, a pureza, a alma celeste de Ester - e de Raquel... Enfim, chegava o negro drama da perseguição: a fuga da família hebraica, através de bosques de bruxas e brutas aldeias feudais; a aparição, numa encruzilhada, do príncipe Franck que vem proteger Ester, de lança alta, no seu grande corcel; o tropel da turba fanática, correndo a queimar o rabino e os seus livros hereges; a batalha, e o príncipe atravessado pelo chuço dum reitre, indo morrer no peito de Ester, que morre com ele num beijo. Tudo 
isto se precipitava como um sonoro e tumultuoso soluço; e era tratado com as maneiras modernas de estilo, o esforço atormentado inchando a expressão, as camadas de cor atiradas à larga para fazer ressaltar o tom de vida...

Ao findar, o Átomo exclamava, com a vasta solenidade dum cheio de órgão: - "assim arrefeceu, parou, aquele coração de herói que eu habitava; e evaporado o princípio de vida, eu, agora livre, remontei aos astros, levando comigo "a essência pura desse amor imortal".

- Então?... disse Ega, esfalfado, quase trémulo.

Carlos só pôde responder:

- Está ardente.

(...)

No entanto, no estrado, o Rufino, um bacharel transmontano, muito trigueiro, de pêra, alargava os braços, celebrava um anjo, "o Anjo da Esmola que ele entrevira, além no azul, batendo as asas de cetim..." Ega não compreendia bem - entalado entre um padre muito gordo que pingava de suor, e um alferes de lunetas escuras. Por fim não se conteve: - "Sobre que está ele a falar?" E foi o padre que o informou, com a face luzidia, inflamada de entusiasmo:

- Tudo sobre a caridade, sobre o progresso! Tem estado sublime... infelizmente está a acabar!

Parecia ser, com efeito, a peroração. O Rufino arrebatara o lenço, limpava a testa lentamente; depois arremeteu para a borda do tablado, voltando-se para as cadeiras reais com um tão ardente gesto de inspiração - que o colete repuxado descobriu o começo da ceroula. Foi então que Ega compreendeu. Rufino estava exaltando uma princesa que dera seiscentos milréis para os inundados do Ribatejo, e ia a benefício deles organizar um bazar na Tapada. Mas não era só essa soberba esmola que deslumbrava o Rufino porque ele, "como todos os homens educados pela filosofia e que têm a verdadeira orientação mental do seu tempo, via nos grandes factos da história não só a sua beleza poética, mas a sua influência social. A multidão, essa, sorria simplesmente, enlevada, para a incomparável poesia da mão calçada de fina luva que se estende para o pobre. Ele porém, filósofo, antevia já, saindo desses delicados dedos de princesa, um resultado bem profundo e formoso... O quê, meus senhores? O renascimento da Fé!"

(...)

$\mathrm{Na}$ sala o silêncio impressionava. Rufino, com gestos de quem traça numa tela linhas lentas e nobres, descrevia a doçura duma aldeia, a aldeia em que ele nascera, ao pôr-do-sol. E o seu vozeirão velava-se, enternecido, morrendo num rumor de crepúsculo.

(...) Rufino, no entanto, com as mãos descaídas, confessava uma fragilidade de sua alma! Apesar da poesia ambiente dessa sua aldeia natal, onde a violeta em cada prado, o rouxinol em cada balseira provavam Deus irrefutavelmente, - ele fora dilacerado pelo espinho da descrença! Sim, quantas vezes, ao cair da tarde, quando os sinos da velha torre choravam no ar a Ave-Maria e no vale cantavam as ceifeiras, ele passara junto da cruz do adro e da cruz do cemitério, atirando-lhes de lado, cruelmente, o sorriso frio de Voltaire!..

Um largo frémito de emoção passou. Vozes sufocadas de gozo mal podiam murmurar "muito bem, muito bem..."

Pois fora nesse estado, devorado pela dúvida, que Rufino ouvira um grito de horror ressoar por sobre o nosso Portugal... Que sucedera? Era a Natureza que atacava seus filhos! - E lançando os braços, como quem se debate numa catástrofe, Rufino pintou a inundação... Aqui aluía um casal, ninho florido de amores; além, na quebrada, passava o balar choroso dos gados; mais longe as negras águas iam juntamente arrastando um botão-de-rosa e um berço!...

Os bravos partiram profundos e roucos de peitos que arfavam. E em torno de Carlos e do Ega, sujeitos voltavam-se apaixonadamente uns para os outros, com um brilho na face, comungando no mesmo entusiasmo: "Que rajadas!... Caramba!... Sublime!..."

Rufino sorria, bebendo esta comoção, que era a obra do seu verbo. Depois, respeitosamente, voltou-se para as cadeiras reais, solenes e vazias...

Vendo que a cólera da Natureza rugia implacável, ele erguera os olhos para o natural abrigo, para o exaltado lugar donde desce a salvação, para o Trono de Portugal! E de repente, deslumbrado, vira por sobre ele estenderem-se as asas brancas dum anjo! Era o anjo da esmola, meus senhores! E donde vinha? donde recebera a inspiração da caridade? donde saía assim, com os seus cabelos de ouro? Dos livros da ciência? dos laboratórios químicos? desses anfiteatros de anatomia onde se nega cobardemente a alma? das secas escolas de filosofia que fazem de Jesus um percursor de Robespierre? Não! Ele ousara interrogar o anjo, submisso, com o joelho em terra. E o anjo da esmola, apontando o espaço divino, murmurara: "Venho dalém!"

Então pelos bancos apinhados correu um sussurro de enlevo. Era como se os estuques do tecto se abrissem, os anjos cantassem no alto. Um estremecimento devoto e poético arrepiava as cuias das senhoras.

E Rufino findava, com uma altiva certeza na alma! Sim, meus senhores! Desde esse momento, a dúvida fora nele como a névoa que o sol, este radiante sol português, desfaz nos ares... E agora, apesar de todas as ironias da ciência, apesar dos escárnios orgulhosos dum Renan, dum Littré e dum Spencer, ele, que recebera a confidência divina, podia ali, com a mão sobre o coração, afirmar a todos bem alto - havia um Céu!

- Apoiado! mugiu na coxia o padre sebento. E por todo o salão, no aperto e no calor do gás, os cavalheiros das Secretarias, da Arcada, da Casa Havanesa, berrando, batendo as mãos afirmaram soberbamente o Céu!

in Os Maias (1888) 


\section{AGORA EM PORTUGAL}
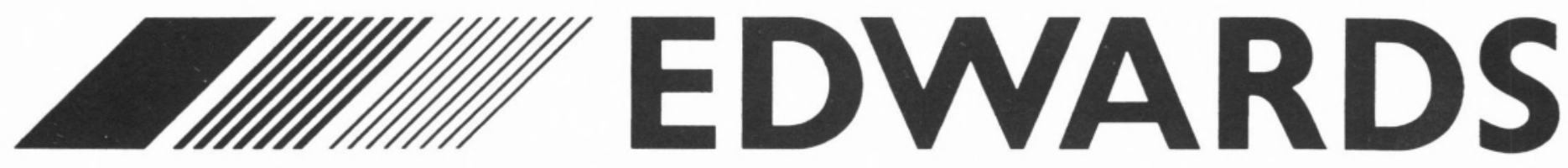

BOMBAS MECÂNICAS DE ALTO VACUO

BOMBAS DE VACUO "SECAS" E SISTEMAS DE TRATAMENTO DE EMISSÕES

BOMBAS DE VACUO PARA VAPORES

BOMBAS DE VACUO TURBOMOLECULARES

BOMBAS CRIOGÉNICAS

MEDIDA E CONTRÔLO DE VACUO

VÁLVULAS

FITTINGS, SELANTES E FLUIDOS

BOMBAS DE VACUO "QUÍMICAS"

SISTEMAS COMPLETOS DE VACUO

LIOFILIZAÇÃO

SISTEMAS DE DEPOSIÇÃO E TRATAMENTO SOB VACUO (SUPTTERING, ELECTRON GUNS)

DETECTORES DE FUGAS

\section{É \\ DIAS DE SOUSA LDA.}

Praceta Anibal Faustino, $n^{\circ} 68$ B 2625 PÓVOA DE STA. IRIA

T: (01) 9592316 / 9594462

FAX: (01) 9590813 / 9564995
Rua Gonçalo Cristóvão, 294, $7^{\circ}$ ET 4000 PORTO

T: (02) $310839 / 2082490$

FAX: (02) 323573
Canada dos Folhadais, $\mathrm{n}^{\circ} 15$ 9700 ANGRA DO HEROÍSMO

T: (095) 32512

FAX: (095) 31338 